\title{
Perceptions of Higher Education Faculty Members on Bilingual Education in Turkey
}

\author{
Dilek İlhan ${ }^{1}$, Hasan Aydın ${ }^{2}$ \\ ${ }^{1}$ Dilek İlhan, Y1ldız Technical Universty, Y1ldız Campus, Besiktas, Istanbul 34349, Turkey \\ ${ }^{2} Y_{1} l d ı z$ Technical University, Faculty of Education, Department of Educational Sciences, Davutpaşa Campus, Esenler, \\ İstanbul 34220, Turkey
}

Correspondence: Dilek Ilhan, Yıldız Technical Universty, Yıldız Campus, Besiktas, Istanbul 34349, Turkey

Received: February 25, 2015 Accepted: March 19, 2015 Online Published: April 17, 2015

doi:10.11114/jets.v3i3.694

URL: http://dx.doi.org/10.11114/jets.v3i3.694

\begin{abstract}
In recent years, bilingual education has been a crucial phenomenon in the educational community in Turkey. This study aims to investigate whether academics have positive perceptions towards bilingual education or not. Regarding this issue, it is important to get the opinions of academics that are responsible for training future teachers. An online scale was emailed to the academics in 74 universities in Turkey. The study utilized quantitative research methods. A total of 208 academics completed the Bilingual Education Percept"ion Scale. Their responses were graded and these grades were used in generating various analyses. Cronbach Alpha reliability analysis was implemented and the reliability coefficient of the scale was determined to be .96 . The mean of academics' scores indicates that they have shown highly positive perceptions about bilingual education. Moreover, demographic data was used as independent variable and regression analysis was performed. The findings of this study showed that academics have shown higher positive perception towards bilingual education.
\end{abstract}

Keywords: bilingualism, bilingual education, academics' perceptions, Turkey

\section{Introduction}

For several decades, bilingual education has always been a controversial issue in the field of education all over the world (Baker, 2001). One of the reasons is allegedly that it threatens a country's sovereignty and unity. However, bilingual and multilingual curricula are being deployed in many ethnically and culturally rich countries such as the United States, Canada, England, Spain, South Africa, and most of the European Countries (Kaya \& Aydin, 2013). Those countries acknowledge the diversity of languages. While they are focusing on the official language and reinforcing it, they also design curricula and models to encompass other languages besides adopting new tools and resources (Ball, 2011). Moreover, some countries teach a second language apart from the official language and adopt it as an educational policy. However, in Turkey, "one language one nation" policy has ruled as an ideology (Gok, 2009). This poses a problem of equal opportunities in education because it is a fundamental human right to be educated in one's mother tongue. In the Convention on the Rights of the Child (1989), the Parties recognize the right of the child to education, and the relevant article suggests that this right be granted progressively with equal opportunity (article 28). For the sake of the development of respect for the child's parents, his or her own cultural identity, language and values, for the national values of the country in which the child is living, the country from which he or she may originate, and for civilizations different from his or her own(article 29/c). Thus, education in the mother tongue plays an important role in incorporating cultural and linguistic richness.

However, when it comes to mother tongue multilingual education in Turkey, Kurdish is what seems to be the only language that comes to mind. Arabs, Circassians, Lazi and other minor ethnic groups are being turned a blind eye, which causes polarizations in the society (Gok, 2009). It is a great loss for a society if the children can't use their fundamental right to be educated in their mother tongue.

The justification given for the lack of multilingual mother tongue education is the idea that the unity and integrity of the country would be compromised. However, variety in language is the symbol of cultural heritage and historical treasure. Language is also very important for the appropriation of the history of the society and the formation of cultural memory. The quality and quantity of a children's exposure to language affects their learning (UNESCO, 2011). In addition, 
Cummins (2001) stresses that rejecting a child's language in the school means rejecting the child himself. Many researchers demonstrate that forcing minority language children to make a transition too soon towards being educated in a new language (e.g. a majority language) can be detrimental to their learning processes and their academic achievement (Kaya \& Aydin, 2013). However, it is known that education in the mother tongue improves academic success, eases the learning process and contributes to the learning of a second language. The learner is able to express himself better in his native language, and the learning process can be realized in terms of a mutual interaction thus making the instruction more effective. If necessary financial resource, support and fundamental requirements of the science of education can indeed be integrated into shaping processes of curricula, simultaneous teaching of the mother tongue and another language dominant in the society can actually increase the child's academic achievement (Tochon, 2008). Bilingualism has positive effects on children's linguistic and educational development (Cummins, 2001). Thus, mother tongue education is not a threat to unity, and on the contrary, it brings people together. Most of the countries which commenced bilingual education have neither been disintegrated nor do disintegration problems cease to exist in countries which use solely the dominant language as the medium of instruction (Kaya \&Aydin, 2013). In fact, bilingualism affects children's academic success in a positive way and brings various linguistic and ethnic communities together. Turkey consists of many different cultural, ethnic and religious groups. Turkey has been taking steps in this direction as well for some time now, though they remain tiny at present. However, the legislations and their implementation need to be better organized. Accordingly, inclusion of the Kurdish language as a selective course in the curricula prepared by the Ministry of National Education and commencing departments of the Kurdish Language and Literature at universities are among the greatest changes that the present government have implemented with a view to ameliorate the bilingual education in Turkey. These important improvements in the Turkish Educational System are a sign of the realization of the notion of bilingual education in Turkey. As the agents of practitioners of this kind of education, it is of great importance to find out about the perceptions of academics, who are responsible for raising these practitioners, towards bilingual education. The purpose of the present study is to determine the perceptions of academics towards bilingual education in Turkey.

\section{Literature Review}

Language is not only a tool for communication and knowledge but also a fundamental attribute of cultural identity and empowerment, both for the individual and the group (UNESCO, 2003). Wei (2012) states that ethnicity, gender, and relations are components of identity; and are extremely important in daily interaction. He also adds that in the world, people are defined as 'them' and 'us,' 'in-group' and 'out-group,' or 'we code' and 'they code.' So the minority people leave their first language and culture aside in order to learn the language of the majority culture. Grosjean (2010) states that though there is not a certain estimate on the number of speakers of two or more languages at the same time, it seems obvious that half of the world's population is bilingual making bilingualism or multilingualism inevitably present in almost every country in the world, whether officially approved or not.

\subsection{Bilingualism as an Educational Right}

Language is crucial for the education of children coming especially from diverse ethnicities; because, most of the minority children are educated in the majority tongue without developing competence in their mother tongue. This can result in low academic performance at school and low academic achievement. Edwards (2012) points out that minority groups have no choice but to live and work surrounded by a majority language, the communicative and the symbolic functions of language split them apart, so medium is not possible for them to sustain their culture and literature. According to the Universal Declaration of Linguistic Rights (1996), 'education must always be at the service of linguistic and cultural diversity and of harmonious relations between different lingual communities throughout the world. Within the context of the foregoing principles, everyone has the right to learn any language' (Article 23, p.7). Chavez (1988) stated that, if the native language has not been developed, the child loses a powerful means of learning. In short, under these conditions the child is denied to be given the right to an equal educational opportunity. Skutnabb-Kangas (1999) stresses that linguistic human rights in education are a precondition for the maintenance of the diversity in the world for which all people should assume responsibility. He also adds that the lack of these rights, namely the absence of these languages from school curricula causes minority languages to be vanished. If these languages are not included in formal education, it causes a loss of diversity due to educational failure, capability deprivation, and poverty for the minorities (Mohanty et al. 2009). Pinnock (2009)'s study on Language and the Missing Link indicates that there are some countries such as Thailand, France, Turkey, Vietnam, Mexico, Germany, Peru, Brazil with large numbers/proportions of population without access to education in mother tongue and its result is a strong likelihood of educational failure and little chance of achieving target skills in international languages for many. Choice in education must attempt to ensure that the use of a particular language as the medium of instruction does not imply condemnation to a low position in a hierarchical linguistic ordering or the exclusion of particular groups from access to power and resources (Kontra et al. 1999). Mohanty (2006) stresses that disabilities and disadvantages are often related 
to minor languages, but it is not inherent to these languages; they are due to unequal treatment and social origins in the society. In addition, Garcia (2009) states that, as agents of the state, schools support monolingualism; but, this prevents bilingual children from using their mother tongue, thus restricting their educational life and opportunities.

\subsection{The Importance of Bilingual Education}

Baker (1996) suggests that when the first language is less well developed, or where there is attempted replacement of the first language by the second language (e.g. in the classroom); the development of the second language may be relatively impeded. Furthermore, by wasting the linguistic resources of the nation, it causes children to be discouraged from developing their mother tongues, and this is obviously not reasonable for national self-interest. (Skutnabb-Kangas, 2000). Furthermore, not being educated in mother tongue is also detrimental to minority children in several aspects. A fast transition to the majority language causes more harm than good. It denies the child's skills in the home language, even denies the identity and self-respect of the child himself (Baker, 1996). Wright (2012) suggests that primary language support can help value and use students' home languages as a resource to help students learn the dominant language and academic content. However, he goes on to say that such support is not sufficient and permanent unless it is able to help students develop their bilingualism and native language skills. Garcia (2009) stresses that for people's educational and social opportunities, the ways minority communities acquire their native languages cannot be turned a blind eye on and must be incorporated into the educational system. Furthermore, Cummins (2001) adds that the final aim of education is supposed to be a form of empowerment which involves collaboration and creating power collectively.

\subsection{Beneficiaries of Bilingual Education}

Baker (2001) states that the interaction between teachers and students can flow more naturally through the use of L1. They can exchange opinions on meaning, conducing participatory teaching and learning as well as influencing the affective domain positively. Furthermore, when the language children use at home, alongside the culture that is inseparable from it, enters the school, identity, individual and group empowerment is facilitated (Cummins, 2000). Thomas and Collier (2002) emphasize that using the primary language in the first four years of education is of utmost importance when the schooling outcome is considered. The first years of schooling are the times when children are to learn how to read, write and do arithmetic, which makes this period crucial.

It can be argued that the programs reinforcing the L1 skills of minority students give better results in terms of school success. Their success reflects both the reinforcement of the cultural identity and cognitive/academic foundation (Skutnabb-Kangas, 1984). Cummins (1988) also stresses that forms of instruction that empowers students will aim to give students sufficient skills so that they stop depending on instruction, encouraging active generation of one's own knowledge. He also states that instructors who consider themselves as helpers on the issue of a second language and cultural affiliation to students' repertoire have much more possibility to empower students when compared to educators that consider themselves as reconstructing a new language upon the ruins of the primary language in part of a process to assimilate them into the dominant culture. Mohanty (2009) reports that:

A bridge from the home language, the mother tongue, to the regional language and to the national language as well as world languages like English; an empowering bridge that leads to meaningful participation in the wider democratic and global setup without homogenizing the beauty of diversity; a bridge that liberates but does not displace (p. 6)

Bilinguals perform better not only in metalinguistic tasks but also in tasks that require higher levels of control (Bialystok, 2003). Adesope et al. (2010) carried out a meta-analysis of 63 studies that examined the cognitive effects associated with bilingualism in children. The results suggest that speaking two languages contributes to one on a cognitive level, conducing better attention control, working memory, abstract and symbolic representation skills, and metalinguistic awareness. Moreover, Kov'acs (2009) examined 3-year-old children on a control task and two theories of mind tasks (standard false-belief task and modified theory of mind task that required understanding others' mental states). The performances of bilingual children were better than monolingual children. She interpreted this outcome as a statement that the precocious development of bilinguals is related to better executive control abilities and not to language-switching knowledge alone.

Hamers and Blanc (2010) states that if a child grows up in two different cultures, both languages contribute to the child's overall development. Hence, an additive form of bilingualism is in question. According to (Benson, 2000), the positive side of using the mother tongue is not only cognitive. For him, classroom participation and self-confidence are also affected positively by this. Smits, Huisman, and Kruijff (2008) found that mother-tongue instruction had a positive effect on educational attendance. If half or more of the schools offered instruction in the mother tongue, the percentage of children out of school would be 10 percent lower on average. As indicated above, bilingualism has positive effects on children's education, it influences children's academic success and life in various aspects. Garcia (2009) states that 
In the twenty-first century, however, we are aware of the linguistic complexity of the world in which monolingual schooling seems utterly inappropriate. Language differences are seen as a resource, and bilingual education, in all its complexity and forms, seems to be the only way to educate as the world moves forward (p. 16).

This being the case, it can be said here that insisting on monolingualism would keep schools from offering a more sophisticated and enhanced learning environment which is more likely to be achieved through bilingualism.

\subsection{Bilingual Education in Turkey}

Turkey has been home to different cultures for all of her history and has constituted a considerable importance owing to her geographical location. Even today, Turkey incorporates various cultures and languages. In this context, it is inevitable that Turkey responds to the needs of those various cultures and languages. According to KONDA (2011), the ethnic infrastructure in Turkey is that the 78.1 per cent of adult citizens are Turkish, 13.1 per cent of adult citizens are Kurdish, and 1.5 per cent of the adult citizens are Lazi and Turkmen. As for a comparative percentage analysis of the language spoken by these people, the 85 per cent of the mother tongue widely spoken is the Turkish language and 13 per cent of it is Kurdish and Zaza languages. Gursel, Kolasin and Altindag (2009) state that \%46 percent of people whose native language is Kurdish, are not primary school graduates. This rate has increased significantly in eastern regions. There are disparities between eastern and western parts of Turkey due to language of instruction. Considering these percentages, it can be said that it is inevitable that these people should be provided with education in their mother tongue. According to Aydin (2012), the need for developing policies in order to meet the educational needs of these people is a priority in eliminating the discrimination between different ethnic groups when it comes to the different ethnic groups and meeting their educational needs. Furthermore, they haven't been able to exercise their right to be educated due to this discrimination. However, not having access to education in mother tongue even causes them to drop out of school. According to a study carried out by Goksen, Cemalcilar \& Gursel (2008), a noticeable result was the ratio of the children who spoke a language other than Turkish at home to the children who dropped out of school. Accordingly, a language other than Turkish is spoken at the houses of the 51.9 per cent of the children who dropped out of school in six provinces (Istanbul, Diyarbakir, Mardin, Sanliurfa, Erzurum, and Konya); this ratio goes up to as high as 85 per cent in Diyarbakir. According to a research carried out by Coskun, Derince and Ucarlar (2010), problems of the children whose mother tongue is Kurdish such as their starting school one step behind, their starting school with no or little knowledge of Turkish, and their failure at school or dropouts. However, Kaya (2011) states that Turkey has a social structure that incorporates multi-ethnicity and multilingualism. Therefore, constitutionally guaranteeing the access for different ethnic groups to equal rights and freedom and relying on expert opinion for conflict resolution regarding any minority-related problems will contribute to bringing the educational system to a higher level of standard. In the light of the discussion above, this study aims to contribute to the solution of instructional problems resulted from bilingual education in Turkey by asking the opinions of the academics, who prepare teachers and who are also the executers of education, towards bilingual education.

\section{Method}

\subsection{Research Design}

This study investigates the perceptions of the academics in Turkey towards bilingual education. This research was carried out with quantitative research method and descriptive survey model using 5-score Likert type scale. In quantitative research, a researcher identifies a research problem and explains relations among variables. With this research design, results indicate a large group of individuals' views on a problem and various views (Creswell, 2012).

\subsection{Participants and Setting}

In this research, 'Bilingual Education Perception Scale' was prepared in survey database and emailed to 3420 academics in 74 universities in Turkey during fall semester in 2013. Academics were invited to participate in the study through e-mail invitations. Academics' mail addresses were reached through universities web sites. 208 academics completed (108 male, 100 female) the survey. All of the academics' answers were evaluated in the survey so the sampling design of the survey is disproportionate sampling.

\section{Research Questions}

1. What are the perceptions of faculty members in Turkey towards bilingual education?

2. Are gender, age, ethnicity, years of experience and academic title significant predictors of academics' perceptions towards bilingual education?

\subsection{Data Collection Tool}

In data collection procedure, the scale prepared in survey database was emailed to 3420 academics in 74 universities. 
From these email addresses, 148 mails failed to deliver to recipients because email accounts did not exist or recipients' mail addresses were wrong. After a month of data analysis procedure (4th December 2013- 5th January 2014), survey and data collection were ended. In this research, survey is made up of two sections. Demographic data (gender, age, marital status, ethnicity, academic title, and years of experience) was collected in the first section. In the second section, there is a "Bilingual Education Perception Scale". In this scale there are 22 items. This scale was graded in 5 score Likert type; "Strongly Disagree (1)", "Disagree (2)", "Neutral (3)", "Agree (4)", "Strongly Agree (5)" The scale was prepared and implemented in Turkish due to the fact that the academics" proficiency levels of language use may be different in each individual. In this study, the reliability coefficient has been calculated through Cronbach's Alpha and the result was .96. This Cronbach's Alpha result suggests that scale is quite reliable to evaluate perceptions towards bilingual education.

\subsection{Data Analysis}

A total of 395 academics participated in "Bilingual Education Perception Scale" designed to serve the purpose of the study but 208 academics completed the survey, 187 academics started the survey but they did not complete it. Mean scores of items in Bilingual Education Perception Scale were computed to determine perceptions of academics towards bilingual education. Mean scores are interpreted in 0.80 ranges (1.00-1.80 very low, 1.81- 2.60 low, 2.61-3.40 medium, 3.41-4.20 high, 4.21- 5.00 very high). Data was analyzed via Statistical Package for the Social Sciences (SPSS, Version 21). Each response by the participants to each item in the survey was scored to analyze the perceptions of the academics; and, mean scores and standard deviation values were calculated. Regression analysis was used to determine whether independent variables were significant predictors of academics' perceptions towards bilingual education.

\section{Results}

In this study, data collected via Bilingual Perception Scale was analyzed and findings were drawn in the light of these results. Perceptions of academics towards bilingual education were determined by the mean scores in the scale. The result of the analysis indicates that academics have shown higher positive perception towards bilingual education. Regression analysis was performed to determine whether demographic information were significant predictors of their perceptions.

Question 1. What are the perceptions of academics towards bilingual education in Turkey?

Table 1. Items and Number of Participants 


\begin{tabular}{|c|c|c|c|c|c|c|c|}
\hline Items & & 1 & 2 & 3 & 4 & 5 & Total \\
\hline 1. & $\begin{array}{l}\text { I believe that each individual must have a right to be educated in his mother } \\
\text { tongue. }\end{array}$ & 20 & 32 & 20 & 73 & 63 & 208 \\
\hline 2. & $\begin{array}{l}\text { I believe that bilingual education will have a positive effect on students' } \\
\text { academic achievement. }\end{array}$ & 28 & 36 & 33 & 70 & 41 & 208 \\
\hline 3. & $\begin{array}{l}\text { I believe that bilingual education will solve the problems resulting from } \\
\text { inequalities. }\end{array}$ & 25 & 52 & 30 & 78 & 23 & 208 \\
\hline 4. & $\begin{array}{l}\text { I believe that bilingual education will be a better ground for equal } \\
\text { opportunities in education }\end{array}$ & 25 & 52 & 20 & 78 & 33 & 208 \\
\hline 5. & $\begin{array}{l}\text { I believe that bilingual education is an opportunity for the students having a } \\
\text { different mother tongue other than the majority of students. }\end{array}$ & 20 & 32 & 26 & 81 & 49 & 208 \\
\hline 6. & $\begin{array}{l}\text { I believe that bilingual education will help students get to know one } \\
\text { another's languages. }\end{array}$ & 22 & 32 & 18 & 88 & 48 & 208 \\
\hline 7. & $\begin{array}{l}\text { I believe that bilingual education will help students get to know one } \\
\text { another's cultures }\end{array}$ & 21 & 29 & 19 & 91 & 48 & 208 \\
\hline 8. & $\begin{array}{l}\text { Courses targeted at raising awareness in candidate teachers should be added } \\
\text { to curriculum in universities. }\end{array}$ & 26 & 31 & 22 & 76 & 53 & 208 \\
\hline 9. & $\begin{array}{l}\text { Teachers should encourage students with different languages to use their } \\
\text { mother tongue. }\end{array}$ & 23 & 38 & 38 & 62 & 47 & 208 \\
\hline 10. & $\begin{array}{l}\text { I believe that bilingual education will increase the ratio of attending school } \\
\text { at the primary school level. }\end{array}$ & 23 & 59 & 30 & 73 & 23 & 208 \\
\hline 11. & $\begin{array}{l}\text { I believe that bilingual education has a unifying nature thanks to its potential } \\
\text { to bring individuals from different languages and cultures. }\end{array}$ & 27 & 32 & 30 & 77 & 42 & 208 \\
\hline 12. & Bilingual education increases tolerance among students. & 26 & 30 & 40 & 69 & 43 & 208 \\
\hline 13. & $\begin{array}{l}\text { I believe that people shouldn't be treated differently because of their ethnic } \\
\text { background. }\end{array}$ & 7 & 3 & 3 & 39 & 156 & 208 \\
\hline 14. & $\begin{array}{l}\text { I believe that people shouldn't be treated differently because of their mother } \\
\text { tongue. }\end{array}$ & 9 & 4 & 2 & 46 & 147 & 208 \\
\hline 15. & $\begin{array}{l}\text { I believe that bilingual education will foster interpersonal communication } \\
\text { with its ability to bring individuals from different cultural backgrounds } \\
\text { together. }\end{array}$ & 23 & 39 & 22 & 71 & 53 & 208 \\
\hline 16. & $\begin{array}{l}\text { I believe that the current educational system meets the needs of the } \\
\text { individuals with different languages }\end{array}$ & 63 & 74 & 28 & 24 & 19 & 208 \\
\hline 17. & $\begin{array}{l}\text { I believe that the educational system must bring balance among the ethnic } \\
\text { structures by overseeing the linguistic diversity. }\end{array}$ & 17 & 36 & 22 & 90 & 43 & 208 \\
\hline 18. & $\begin{array}{l}\text { I believe that the educational system must bring balance among the ethnic } \\
\text { structures by overseeing the cultural diversity. }\end{array}$ & 14 & 17 & 18 & 96 & 63 & 208 \\
\hline 19. & $\begin{array}{l}\text { I believe that ignoring linguistic differences deteriorates the general quality } \\
\text { of education. }\end{array}$ & 28 & 48 & 26 & 65 & 41 & 208 \\
\hline 20. & $\begin{array}{l}\text { Implementing bilingual education will enable minority students to be more } \\
\text { psychologically comfortable. }\end{array}$ & 25 & 33 & 23 & 76 & 51 & 208 \\
\hline 21. & Implementing bilingual education will serve the democracy as well & 30 & 36 & 29 & 57 & 56 & 208 \\
\hline 22. & $\begin{array}{l}\text { I am in favor of bilingual education. } \\
\text { Mean Percentage }(\%)\end{array}$ & 41 & $\begin{array}{l}23 \\
1678\end{array}$ & 33 & $\begin{array}{l}56 \\
3356\end{array}$ & 55 & 208 \\
\hline
\end{tabular}

Table 1 indicates that academics responded to items as Agree (\%33.56) and Strongly Agree (\%26.15). It can be inferred that academics have shown higher positive perception towards bilingual education. More detailed information can be drawn from mean scores and the standard deviation values of academics' perception towards bilingual education in Bilingual Education Perception Scale.

Table 2. Mean Scores and Standard Deviation Values in Bilingual Education Perception Scale 


\begin{tabular}{|c|c|c|c|c|}
\hline Items & & $\mathrm{X}$ & SS & $\mathrm{N}$ \\
\hline 1. & I believe that each individual must have a right to be educated in his mother tongue. & 3,61 & 1,31 & 208 \\
\hline 2. & I believe that bilingual education will have a positive effect on students' academic achievement. & 3,29 & 1,32 & 208 \\
\hline 3. & I believe that bilingual education will solve the problems resulting from inequalities. & 3,11 & 1,24 & 208 \\
\hline 4. & I believe that bilingual education will be a better ground for equal opportunities in education & 3,20 & 1,30 & 208 \\
\hline 5. & $\begin{array}{l}\text { I believe that bilingual education is an opportunity for the students having a different mother tongue other } \\
\text { than the majority of students. }\end{array}$ & 3,51 & 1,27 & 208 \\
\hline 6. & I believe that bilingual education will help students get to know one another's languages. & 3,52 & 1,28 & 208 \\
\hline 7. & I believe that bilingual education will help students get to know one another's cultures & 3,56 & 1,26 & 208 \\
\hline 8. & Courses targeted at raising awareness in candidate teachers should be added to curriculum in ur & 3,48 & 1,34 & 208 \\
\hline 9. & $\mathrm{Te}$ & 3,35 & 1,31 & 208 \\
\hline 10. & I bel & 3,07 & 1,23 & 208 \\
\hline 11. & $\begin{array}{l}\text { ducation has a unifying nature thanks to its potential to bring individuals from } \\
\text { ultures. }\end{array}$ & 3,36 & 1,31 & 208 \\
\hline 12. & Bili & 3,35 & 1,29 & 208 \\
\hline 13. & I bel & 4,61 & ,87 & 208 \\
\hline 14. & I bel & 4,53 & ,95 & 208 \\
\hline 15. & $\begin{array}{l}\text { I believe that bilingual education will foster interpersonal communication with its ability to bring } \\
\text { individuals from different cultural backgrounds together. }\end{array}$ & 3,44 & 1,34 & 208 \\
\hline 16. & I bel & 2,34 & 1,27 & 208 \\
\hline 17. & $\begin{array}{l}\text { I believe that the educational system must bring balance among the ethnic structures by overseeing the } \\
\text { linguistic diversity. }\end{array}$ & 3,51 & 1,22 & 208 \\
\hline 18. & $\begin{array}{l}\text { I believe that the educational system must bring balance among the ethnic structures by overseeing the } \\
\text { cultural diversity. }\end{array}$ & 3,85 & 1,41 & 208 \\
\hline 19. & I bel & 3,21 & 1,35 & 208 \\
\hline 20. & & 3,46 & 1,33 & 208 \\
\hline & Implementing bilingual education will serve democracy as well & 3,35 & 1,41 & 208 \\
\hline 22. & I am in favor of bilingual education. & 3,29 & 1,46 & 208 \\
\hline
\end{tabular}

As presented in Table 2, the 13th item has the highest mean score with 4,61. In this item, "I believe that people shouldn't be treated differently because of their ethnic background." out of 208 participants, 7 participants "Strongly Disagree", 3 participants "Disagree", 3 participants respond as "Neutral", 39 participants "Agree", 156 participants respond as "Strongly Agree".

As presented in Table 2, the 16th item has the lowest mean score with 2,34. In this item, "I believe that the current educational system meets the needs of the individuals with different languages"; out of 208 participants, 63 participants "Strongly Disagree", 74 participants "Disagree", 28 participants respond as "Neutral", 24 participants "Agree”, 19 participants respond as "Strongly Agree".

As can be seen in Table 2, the 22nd item has the highest standard deviation value with 1,46, the 13th item has the lowest standard deviation value with 0,87 . In item 22 , "I am in favor of bilingual education", there is a high level of differentiation. In item 13, "I believe that people shouldn't be treated differently because of their ethnic background.", there is a low level of differentiation. A high standard deviation indicates a heterogeneous group.

Table 3. The number of academics in score ranges

\begin{tabular}{|c|c|c|c|c|c|c|}
\hline $\begin{array}{l}\text { Degrees and } \\
\text { Scores }\end{array}$ & $\begin{array}{l}\text { Very Low } \\
(1.00-1.80) \\
\end{array}$ & $\begin{array}{l}\text { Low } \\
(1.81-2.60)\end{array}$ & $\begin{array}{l}\text { Medium } \\
(2.61-3.40)\end{array}$ & $\begin{array}{l}\text { High } \\
(3.41-4.20)\end{array}$ & $\begin{array}{l}\text { Very High } \\
(4.21-5.00)\end{array}$ & Total \\
\hline $\begin{array}{l}\text { Number of } \\
\text { People }\end{array}$ & 13 & 36 & 33 & 80 & 46 & 208 \\
\hline $\begin{array}{l}\text { Percentage } \\
(\%)\end{array}$ & 6.25 & 17.30 & 15.86 & 38.46 & 22.11 & \\
\hline
\end{tabular}

As presented in Table 3, the number of academics in scores ranges can be seen. In this table, 13 (\%6.25) academics scored very low, 36 (\%17.30) academics scored low, 33 (\%15.86) academics scored medium, 80 (\%38.46) academics scored high, $46(\% 22.11)$ academics scored very high. It can be inferred from that the most accumulated part is the percentage of \%38.46, with 80 academics. It indicates that academics have shown higher positive perception towards bilingual education in Turkey.

Table 4. Mean Scores of Academics

\begin{tabular}{lc}
\hline Number of People & 208 \\
\hline Mean & 3,45 \\
\hline
\end{tabular}

As seen in Table 4, the mean score of academics was found to be 3,45. This score is in the high category (3.41-4.20). This result also indicates that academics have shown higher positive perception towards bilingual education. 
Question 2: Are gender, age, ethnicity, years of experience and academic title significant predictors of academics' perceptions towards bilingual education?

Regression analysis was performed to inquire into whether independent variables were significant predictors of academics' perceptions of bilingual education.

Table 5. Views regarding Bilingual Education as Dependent Variable Multiple Regression Summary

\begin{tabular}{llll}
\hline Model & $\mathrm{R}$ & $\mathrm{R}^{2}$ & Std. Error of the Estimate \\
\hline 1 & .35 & .12 & .89 \\
\hline
\end{tabular}

Table 5 indicates that gender, age range, academic title, ethnicity and academic experience as independent variables predict the variance of mean score in the dependent variable by $\% 12$, because $\mathrm{R}^{2}$ value is 12 . It can be inferred that independent variables affect the dependent variable in a very low degree.

Table 6. ANOVA Results regarding Regression Analysis

\begin{tabular}{llllll}
\hline Model & Sum of Squares & Df & Mean Square & F & P \\
\hline Regression & 24.05 & 5 & 4,81 & 5,89 & .000 \\
\hline
\end{tabular}

Table 6 indicates $p=00$. There is a significant difference between variables $(\mathrm{p}<0.05)$. The level of significance of this difference can also be seen in the Multiple Regression Analysis Table below.

Table 7. Regression Analysis of Bilingual Education Perceptions as Dependent Variables

\begin{tabular}{llllll}
\hline & \multicolumn{3}{l}{$\begin{array}{l}\text { Unstandardized } \\
\text { Coefficients }\end{array}$} & \multicolumn{4}{l}{$\begin{array}{l}\text { Standardized } \\
\text { Coefficients }\end{array}$} \\
\hline Model & $\mathrm{B}$ & Std. Error & Beta & $\mathrm{t}$ & $\mathrm{P}$ \\
Constant & 3,71 &, 37 & & 9,87 &, 00 \\
Gender &,- 021 &, 12 &,- 011 &,- 16 &, 86 \\
Age Range &,- 008 &, 079 &,- 012 &,- 096 &, 92 \\
Ethnicity &, 089 &, 019 &, 317 & 4,76 &, 00 \\
Academic Title &,- 020 &, 028 &,- 072 &,- 716 &, 475 \\
Academic Experience &,- 158 &, 099 &,- 184 & $-1,59$ &, 112 \\
\hline
\end{tabular}

Table 7 presents the following results: Gender $\mathrm{p}=, 86$, Age range $\mathrm{p}=, 92$, ethnicity $\mathrm{p}=, 00$, academic title $\mathrm{p}=, 47$, academic experience $\mathrm{p}=, 11$. Except for ethnicity, other variables are $\mathrm{p}>0.05$. Genders, Age range, Academic Title, Academic Experience are not significant predictors for the perception towards bilingual education.

\section{Conclusion and Discussion}

In the 21 st century, education must effectively address the instructional needs of individuals from linguistic and cultural diversities based on global changes all the over the world. This research particularly focuses on academics' perceptions of bilingual education in Turkey. In this study, it was concluded that academics have shown higher positive perception towards bilingual education. According to Gumus (2010), \%69 percent of the population think that each individual has a right to be educated in their mother tongue. The study also indicates that $\% 48$ people have a higher positive attitude towards education in other languages other than Turkish.

As mentioned in the findings, it was discovered that many academics has disagreed that the current education system meets the needs of the individuals with different languages. Therefore, it is possible to say that the current educational system has not been able to meet educational needs of children coming from different ethnic background. According to Aksu, Erguvanlı and Bekman (2002) conducted an interview with preschool and 1st grade primary school teachers in İstanbul, Diyarbakır and Van to identify the needs of preschool education in Turkey. According to most of the teachers, students' competence in the Turkish language is inadequate. Teachers state that students, especially in Diyarbakır and Van, learn to read and write too late. They also add that students often have difficulty in expressing themselves. They pointed out that a reason for this can be the absence of the special methods for the students whose mother tongue is not Turkish. Moreover, Firat (2010), carried out an interview with primary and secondary school teachers, students and some occupational groups in 20 different cities in Turkey. Most of the people participating in the study state that education should foster respect for diversities rather than eliminating them. Teachers also emphasize that they have a significant role in the appreciation of differences. They should also confront biases and develop respect for differences themselves.

Another result shows that academics has supported that people shouldn't be treated differently because of their ethnic background. Can, Gok and Simsek (2013) conducted a study with students, parents and teachers in Van, Muș, and İstanbul, especially in regions receiving a massive amount of immigration from Eastern Anatolia and Southeastern Anatolia. They held focus group meetings and face to face interviews with participants. Teachers state that it is quite important to show respect for linguistic and cultural diversities. The study indicates that teachers have positive attitudes towards mother tongue based instruction. Moreover, most of the teachers in Van point out that student, especially in the 
early years of education, experience a lack of confidence and fail because they are not recognized due to their mother tongue and they do not use their mother tongue at school. All of these studies indicate that bilingual education makes a major contribution to learners' academic achievement and competence at school. Bilingual education is practiced in many parts of the world such as Canada, Spain and England. Problems that stem from differences have been eased through the implementation of bilingual education and many people from different ethnic backgrounds live in harmony in those countries. It is known that people from 36 different ethnic backgrounds live in Turkey. It is predicted that problems resulting from this fact can be eliminated through bilingual education. In the light of academics' positive attitudes, reforms regarding bilingual education should be made. Further studies are needed on parents' perceptions, students and people's perceptions and instructional programs.

\section{References}

Adesope, O., Lavin, T., Thompson, T., \& Ungerleider, C. (2010). A systematic review and meta- analysis of the cognitive correlates of bilingualism. Review of Educational Research, 80(2), 207-245. http://dx.doi.org/10.3102/0034654310368803

Aksu-Koc, A., Taylan, E. E., \& Bekman, S. (2002). Türkiye'de okul öncesi hizmete duyulan ihtiyaçların belirlenmesi ve çocuğun dil yetisi düzeyinin değerlendirilmesi. ACEV Press, Istanbul

Aydin, H. (2012). Multicultural Education Curriculum Development in Turkey. Mediterranean Journal of Social Sciences, 3(3) 277-286.

Baker, C. (1996). Foundations of bilingual education and bilingualism. Clevedon: Multilingual Matters.

Baker, C. (2001). Foundations of bilingual education and bilingualism (3rd ed.). Clevedon: Multilingual Matters.

Ball, J. (2011). Enhancing Learning of Children from Diverse Language Backgrounds. France: UNESCO.

Benson, C. J. (2000). The primary bilingual education experiment in Mozambique, 1993 to 1997. International Journal of Bilingual Education and Bilingualism, 3(3), 149-166. http://dx.doi.org/10.1080/13670050008667704

Bialystok, E. (2003). Bilingualism in development: Language, literacy, and control. New York: Cambridge University Press.

Can, B., Gök, F., \& Şimşek, S. (2013). Toplumsal Barışın İnşasında Öğretmenlerin Rolü. İstanbul: Helsinki Yurttaşlar Derneği.

Chavez, E. H. (1988). Language policy and language rights in the US: Issues in bilingualism. J. Cummins, \& T. Skutnabb-Kangas (Eds.), Minority education: From shame to struggle, multilingual matters. Clevedon.

Coskun, V., Derince, M. S., \& Ucarlar, N. (2010). Dil yarası: Türkiye'de eğitimde anadilinin kullanılmaması sorunu ve Kürt öğrencilerin deneyimleri. Istanbul: DISA.

Creswell, J. (2012). Educational Research Planning, Conducting, and Evaluating Quantitative and Qualitative Research. Boston: Pearson.

Cummins, J. (1988). From multicultural to antiracist education: An analysis of programmes and policies in Ontario. In J. Cummins, \& T. Skutnabb-Kangas (Eds.), Minority education: From shame to struggle. Clevedon: Multilingual Matters.

Cummins, J. (2000). Language, power and pedagogy. Bilingual children in the crossfire. Clevedon: Multilingual Matters.

Cummins, J. (2001). Bilingual children's mother tongue: Why is it important for education? Sprogforum, 7(19), 15-20. http://www15.gencat.net/pres_casa_llengues/uploads/articles/Bilingual\%20Childrens\%20Mother\%20Tongue.pdf

Cummins, J. (2003). Bilingual Education. In J. Bourne, \& E. Reid. (Eds.)Language Education: World Yearbook of Education (pp. 3-19). London: UK: British Library Cataloguing in Publishing Data. http://dx.doi.org/10.4324/9780203416709_chapter_1

Edwards, J. (2012). Bilingualism and Multilingualism: Some Central Concepts. In T. Bhatia, \& W. Ritchie. (Eds.)The Handbook of Bilingualism and Multilingualism. (2nd ed.). (pp. 5-25). Oxford: Wiley-Blackwell. http://dx.doi.org/10.1002/9781118332382.ch1

Fırat, B. Ş. (2010). Eğitim Sürecinde Kimlik Çatışma ve Barışa Dair Algı ve Deneyimler. İstanbul: Tarih Vakfı.

Garcia, O. (2009). Education and miltilingualism and translanguaging in 21st century. In R. P. Tove Skutnabb-Kangas (Ed.), Social justice through multilingual education (Linguistic diversity and language rights. Bristol: Multilingual Matters.

Gök, F. (2010). Mother Tongue Based Education in the Context of Educational Rights. The Importance of Mother Tongue and Education, 73-83. Ankara: Eğitim Sen. 
Gökşen, F., Cemalcılar, Z., \& Gurlesel, F. (2008). Türkiye'de ilköğretim okullarında okulu terk ile izlenmesi ve önlenmesine yönelik politikalar. Istanbul: ERG, AÇEV, KA.DER. http://spm.ku.edu.tr/wp-content/uploads/pdf/okulterk.pdf

Grosjean, F. (2010). Bilingual: Life and Reality. Cambridge MA: Harvard University Press.

Gümüş, A. (2010). Eğitimde Anadilinin Kullanımı ve Çift Dilli Eğitime Dair Halkın Tutum ve Görüşleri. Eğitim Bilim Toplum, 52-74.

Gürsel, S., Kolaşin, G. U., \& Altındağ, O. (2009). Anadili Türkçe Olan Nüfus ile Kürtçe Olan Nüfus Arasında Eğitim Uçurumu Var. İstanbul: BETAM.

Hamers, J., \& Blanc, H. (2000). Bilinguality and Bilingualism. New York: Cambridge University Press. http://dx.doi.org/10.1017/CBO9780511605796

Kaya, I., \& Aydin, H. (2013). Challenges, Experiences, and Model Recommendations for Bilingual Education. Istanbul: UKAM Press.

Kaya, N. (2011). Türkiye'nin Eğitim Sisteminde Azınlıklar ve Ayrımcılık: Kavramsal Çerçeve ve Temel Sorunlar. İstanbul Bilgi Üniversitesi. http://www.secbir.org/wp-content/uploads/2011/01/18-NURCAN-KAYA.pdf

KONDA. (2011). Kürt Meselesinde Algı ve Beklentiler. Istanbul: Iletisim Yayınları.

Kontra, M., Philipson, R., Skuttnab-Kangas, T., \& Varady, T. (1999). Conceptualising and implementing linguistic human rights. In M. Kontra, R. Philipson, T. Skuttnab-Kangas, \& T. Varady (Eds.), Language, a right and a resource: Approaching linguistic human rights. Badapest: Central European University Press.

Kov'acs, A. (2009). Early Bilingualism enhances mechanisms of false- belief reasoning. Developmental Science, 12, 48-54. http://dx.doi.org/10.1111/j.1467-7687.2008.00742.x

Mohanty, A. K. (2006). Languages in education and globalization. In T. S.-K.-G. Ofelia Garcia (Ed.), Imagining Multilingual Schools. Clevedon: Multilingual Matters.

Mohanty, A. K. (2009). Multilingual education: A bridge too far? In T. Scutnabb-Kangas, R. Philipson, A. K. Mohanty, \& M. Panda (Eds.), Social justice through multilingual education (Linguistic diversity and language rights. Bristol: Multilingual Matters.

Mohanty, A. K., Mishra, M. K., Reddy, N. U., \& Ramesh, G. (2009). Overcoming the language barrier for tribal children: Multilingual education in Andhra Pradesh and Orissa, India. In Social justice through multilingual education (linguistic diversity and language rights. Bristol: Multilingual Matters.

Pinnock, H. (2009). Language and education: The missing link (How the language used in schools threatens the achievement of education for all. Paris: United Nations Educational, Scientific and Cultural Organization.

Skutnabb-Kangas, T. (1984). Bilingualism or not: The education of minorities. Clevedon: Multilingual Matters.

Skutnabb-Kangas, T. (1999). Education of Minorities. In J. Fishman (Ed.), Handbook of Language and Ethnic Identity. New York: Oxford University Press.

Smiths, J., Huisman, J., \& Kruijff, K. (2008). Home language and education in the developing world. Paris: United Nations Educational, Scientific and Cultural Organization.

Thomas, W., \& Collier, V. (2002). A national study of school effectiveness for language minority students' long term academic achievement. Santa Cruz CA: Diversity\& Excellence.

UNESCO Atlas of the World's Languages in Danger. UNESCO Atlas of the World's Languages in Danger, http://www.unesco.org/culture/languages-atlas/index.php

UNESCO. (2003). Education in a multilingual world. Paris: United Nations Educational, Scientific and Cultural Organization.

Wei, L. (2012). Language and Identity. In T. Bhatia, \& W. Ritchie. (Eds.), the Handbook of Bilingualism and Multilingualism. (2nd ed.).(pp. 26-52). Oxford: Wiley- Blackwell. http://dx.doi.org/10.1002/9781118332382.ch2

Wright, W. (2012). Bilingual Education. In T. Bhatia, \& W. Ritchie. (Eds.), the Handbook of Bilingualism and Multlingualism. (2nd $\quad$ ed.). (pp. 598-623). Oxford: Wiley-Blackwell. http://dx.doi.org/10.1002/9781118332382.ch24

\section{$(\mathrm{Cc}) \mathrm{BY}$}

This work is licensed under a Creative Commons Attribution 3.0 License. 